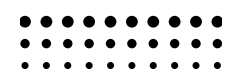

\title{
A Brief History of the Dilemma Action
}

ere's the foundational assumption of this essay: any
resistance movement has a much greater chance at success if its leaders choose nonviolent action.

You may opt to engage in nonviolent resistance, following the teachings of Mohandas K. Gandhi or Martin Luther King Jr., on principle alone. But even if you aren't swayed by that, nonviolence is a better strategic choice because it works. So, if you don't choose it on principle, choose it for its success rate.

Many people assume that violence is the only way to overthrow a violent regime. There is clear proof, however, that nonviolence is a better political strategy for resistance groups. A study conducted by Erica Chenoweth and Maria J. Stephan found that nonviolent movements are twice as likely to succeed as violent movements. ${ }^{5}$ Nonviolent protests have a success rate of 53 percent, in contrast with 
23 percent success for protests with violence. They also showed that when we talk about winning converts over to a cause, the bar isn't really that high. They explain that if just 3.55 percent of the population participates in your movement, it guarantees political change. That's right. Movements with active support of only 3.55 percent of the population have never failed. ${ }^{6}$ Also, Chenoweth and Stephan show clear evidence that it is easier to expand your ranks if your campaign is seen as representing a broad view. If you appear extremist or on the fringe, potential supporters are likely to shy away from you.

Even better, research also proves that it is a lot harder for authorities to use violence against a nonviolent action. As you saw in the kissing protest, when those involved are laughing and having fun, police belligerence isn't going to help the regime. It will look heavy-handed and send even more centrists flying into the arms of the resistance.

If these aren't enough reasons to choose nonviolence, there are more.

Dilemma actions are a key tool in nonviolent resistance because they have worked for decades. Gandhi, in fact, was an early practitioner. But while this sort of resistance has a long history, and while scholars have made efforts to theorize and describe it, no systematic, clear, and specific "strategic framework" for devising adaptable dilemma actions has existed until now. If protests are to work reliably, wherever people are repressed by undemocratic regimes, budding 
activists need to know how to effectively design them. A clear blueprint for developing a dilemma action will help activists assess their unique situations of repression so that they can put oppressive power in a lose-lose situation, one that attracts positive media attention and expands the membership of the nonviolent movement.

Dilemma actions, according to our experience and research and discussed in our "CANVAS Core Curriculum-Guide to Effective Nonviolent Struggle," ideally put the opponent in a situation where it must either (a) grant a nonviolent movement's demand, or (b) act in a way that sacrifices some of its own support and damages its public image. ${ }^{7}$ Historically, dilemma actions have proved to expand the political space and given movements small victories that help them build momentum and a record of success. Part of that success stems from being rooted in popular, easy-to-agree-with beliefs (like the idea that young people should be allowed to kiss). Media attention follows, as does a swath of public opinion. This is why, for example, something like the national anthem protests by US National Football League players sparked such controversy and were unsuccessful. Initially, players nonviolently protested against police brutality and for African American rights; but as the media conversation shifted to whether the protest disrespected the national anthem (and by extension, the flag and military veterans' sacrifices), the initial, easy-to-agree-with issue became a different, controversial one. The public debated whether the national anthem 
should be uniformly respected at football games, instead of joining a protest over blatant racial disparities.

Activists who tap into broad public sentiment are more likely to precipitate a response from those in power than activists who seem fringe. If you can be marginalized, then those in power can ignore you. This is why, for example, when women leave their homes to march and bang pots, they get a lot of attention. These sorts of nonviolent protests are easy for others to join, even if they are not true dilemma actions that require a response.

Also, when the activists who are performing dilemma actions are individually popular and visible, the dilemma they present to their opponent is even greater. That is, high public regard protects you and makes you harder to ignore. This is one place where humor and playfulness really help. In the United States the Yes Men (Andy Bichlbaum and Mike Bonanno) impersonate businessmen to shame the actual businesses they are impersonating. ${ }^{8}$ In one hilarious example, Bichlbaum impersonated a Dow Chemical spokesperson on BBC World on the twentieth anniversary of the Bhopal disaster. ${ }^{9}$ Dressed in a suit and looking quite serious, he apologized for Dow's actions and stated that they planned to sell Union Carbide, the company responsible for the chemical disaster, and use the $\$ 12$ billion in profits to pay for medical care, environmental remediation, and to fund research into the hazards of other Dow products. The whole thing was a hoax. But it worked. It drew massive mainstream attention 
to Dow's failed response to the disaster, and one reason it did so was that Bichlbaum was such an earnest and likable prankster.

The first well-documented example of an ingenious dilemma action was the Salt March campaign of 1930, launched by Gandhi during the Indian independence struggle against British colonial occupation. In short: making salt required only boiling seawater and collecting the salt residue, but the British passed laws granting themselves control of the production of salt, generating tax income for the colonial government. ${ }^{10}$ When Gandhi organized mass defiance of the British salt law, the British government was faced with a dilemma about how to respond. If the British occupiers arrested Gandhi and other salt-law breakers, they would look ridiculous for being so repressive about something as simple and basic to everyone's life as salt. This would damage their legitimacy and make heroes out of the activists. However, if they did not take action against the salt-law breakers, they would not only lose the salt monopoly and tax revenues, they would also lose authority in the eyes of the millions of people that they were trying to rule. The British opted to arrest Gandhi, a move that made them look excessively repressive, and the rest is history.

Another well-known example of a dilemma action was the "Farmer's Hat" protest by the Burmese opposition during the darkest times of the military dictatorship and oppression. The bamboo farmer's hat was a traditional garment for 
hundreds of thousands of Burmese farmers. It also symbolized the National League for Democracy party, which was headed by the Nobel laureate Aung San Suu Kyi, during the campaign leading to the May 1990 elections. The nonviolent action of simply wearing a hat, which the regime had prohibited as "subversive," created a dilemma for the ruling military authority (commonly referred to as SLORC). If SLORC arrested people for wearing a common hat, it would lose additional credibility among the populace. But if SLORC did nothing and allowed people to wear the hat without punishment, then the population could openly flout the regime. ${ }^{11}$ Given the extraordinarily repressive nature of SLORC, one might have expected them to immediately arrest the hat wearers, but instead, they delayed in reacting-a move that allowed the act of wearing these hats to become widespread. Their inability to deal with this low-risk dilemma action on a national level encouraged thousands of prodemocracy Burmese to wear these hats. These simple bamboo hats thus became a national symbol of the opposition for the next decade and helped build momentum for the resistance.

Other contemporary and widely reported dilemma actions come from struggles for racial equality. During the US civil rights movement, African Americans and their allies violated a ban that prevented black patrons from sitting and eating at the lunch counters of restaurants and department stores in Nashville, Tennessee (and elsewhere). This nonviolent direct action was designed not only to create a dilemma 
for local authorities and businesses, but also to overturn the myth that all white Americans supported racial segregation. During several sit-ins, lunch counters were disrupted and businesses lost money. Media coverage increased, as over a hundred black students and white supporters were arrested in the face of police intimidation and violence by citizens. Protest telegrams began to come in from across the country, including from celebrities such as singer Harry Belafonte and former first lady Eleanor Roosevelt. The mayor of Nashville was faced with a dilemma. Keeping the students off segregated lunch counters and putting them in jail by the hundreds would hurt the city's reputation and outrage business owners more than allowing them to continue breaking segregation laws. In the end, the movement won and the lunch counters became integrated, although American's broader fight for racial justice continues to this day.

\section{Laughing Makes a Difference}

ometimes dilemma actions are spiced with an element of Ohumor. In those cases, we are looking at a specific strategic application of a tactic we popularly call laughtivism. In Serbia in 1999, I and dozens of my friends founded the nonviolent youth movement, Otpor. We frequently and strategically used this specific form of dilemma actionlaughtivism-to challenge and ridicule Serbian dictator 
Slobodan Milošević and his unpopular wife, Mirjana Marković. Mocking and teasing created a dilemma for the police, who were faced with two unfavorable choices: (a) arrest harmless, popular young people who were making others laugh, along with a ton of pedestrians and random passersby who were enjoying their own participation in street theater; or (b) ignore the action, disobey an order to stop the "humiliation" of the dictator and his family, and thus encourage other groups and individuals to challenge the regime in a similar manner.

One of our most successful dilemma actions was called "Dime for Change." My fellow Otpor activists painted a picture of Slobodan Milošević’s face onto a large petrol barrel in a downtown shopping area in the capital city of Belgrade. People were invited to throw a few "dimes for change" into the barrel and buy themselves a chance to hit the painted portrait of our dear president with a bat. Soon curious bystanders lined up for a swing. People started to stare, then to point, then to laugh. Before long some parents were encouraging their children who were too small for the bat to kick the barrel. Everybody was having fun, and the clang of the barrel echoed all the way down to Kalemegdan Park. It didn't take long for the president's portrait to get beaten beyond recognition.

As this was happening, my friends and I were sitting outside an adjacent café. It was fun to see all these people blowing off steam. But the best part, we knew, still lay ahead. Ten 
minutes later, a patrol car stopped nearby and two pudgy policemen stepped out. The Serbian police's first instinct, we knew, would be to arrest perpetrators and protesters. Ordinarily they'd arrest the demonstration's organizers, but we were anonymously spectating from a busy café. That left the officers with only two bad choices. They could arrest the people lining up to smack the barrel-including waiters from nearby cafés, people holding shopping bags, and a bunch of parents with children-or they could just arrest the barrel itself. If they went for the people, they would cause an outrage, as there's hardly a law on the books prohibiting violence against rusty metal cylinders, and mass arrests of innocent bystanders are the surest way for a regime to radicalize even its passive citizens.

The two rotund officers shooed away the onlookers, positioned themselves on either side of the filthy barrel, and hauled it off in their squad car. But of course, we had invited several photojournalists to our spectacle-the next day, our stunt ended up on the cover of two national newspapers, the type of publicity that you literally couldn't buy. That picture-two policemen dragging an old barrel with Miloševićs face to the patrol car-was truly worth a thousand words. It told anyone who so much as glimpsed it that Miloševićs feared police had been turned into a punchline.

We were so proud of our little prank. We naively thought that we, the Serbs, were the first to marry a dilemma action 
with an element of humor and mockery. We boldly even decided to give it a label, laughtivism. You can imagine how disappointed I was later, as I started doing more research on nonviolent protests, to find that our approach had already been invented decades ago.

Consider the Polish Solidarity movement. It was a cold February evening in 1982 when the people of Świdnik, a small town in eastern Poland, took their television sets for a walk. Tired of the nightly routine of watching smiley announcers with fancy haircuts reading governmentapproved scripts that were ridiculously rosy and full of lies, activists decided to protest by not watching the news. But for the boycott to work, it had to be both public and subtle enough to avoid a police crackdown. Like comics trying out new material, they improvised. At first, they made a point of unplugging their sets and placing them on their windowsills every evening at 7:30 p.m. It was a good first step, but it wasn't funny, and therefore it was uninspiring. So someone procured a bunch of wheelbarrows and encouraged their friends to take their TVs down to the street, load them up, and wheel them around town. Before too long, anyone walking the streets of Swidnik at dusk could see friends and neighbors ambling and laughing, pushing along wheelbarrows like baby carriages, holding TVs instead of babies, using the half-hour previously spent listening to the official newscast to greet one another, gossip, and share in the thrill of standing up to the regime together. 
It was a great gag, and the practice soon spread to other Polish towns. Flabbergasted, the government weighed its options. It couldn't arrest anyone; there was no law specifying that Polish citizens couldn't push a TV down the street. All they could do was move the 10 p.m. curfew up to 7:00 p.m., thereby forcing everyone indoors and thus showing their powerlessness to contain criticism, a move that outraged the Polish public even more.

\section{Dilemma Actions Today}

Wile nonviolent action wasn't new in the twentieth
century, there is no doubt that it began as a conscious political strategy in the twentieth century and that its use is on the rise in the twenty-first. ${ }^{12}$ As I mentioned earlier, Gandhi really did start something with his Salt March. Not only did he succeed, but his tactics also got so much attention that other resistance movements emulated and adapted them. We witnessed the same thing with Otpor's tactics, too. Activists in Georgia, Ukraine, Kyrgyzstan, Belarus, and Lebanon looked to us as models for their own resistance movements-and this process is ongoing. Imitation really is the sincerest form of flattery.

So how have things changed since Gandhi? One clear shift is in how movements communicate their message to the public. Technology, especially social media, has changed 
the landscape of the world's activism. How dilemma actions look-and what results they get-in the digital era is an important question with unexpectedly inspiring answers.

A hallmark of all activist creativity is that the action has unexpected or surprising developments. Today, results can be astonishing because an action might go viral. Very often what seems to be a lonely protest by a creative individual or small group can spark mass mobilization beyond expectations. Sometimes all it takes for successful mobilization is personal courage, powerful storytelling, and access to a social media account.

Let me give you an example that will surprise you.

One of the best examples of how technology can spark effective resistance comes to us from Zimbabwe. At the time of this action, Zimbabwe was a low-tech country ruled by a despot, Robert Mugabe, and its people faced historic levels of oppression, apathy, and fear. On April 20, 2016, Pastor Evan Mawarire made a Facebook post. In a four-minute inspirational video entitled "This Flag," Mawarire built on the poetics of anticolonial resistance and nationalization to create a rallying cry. In the video, Mawarire wears his country's flag while lamenting "the country's moribund economy, corruption, and human rights abuses." 13

The video led to a hashtag \#ThisFlag, which created a powerful bridge between social media and grassroots resistance. As the hashtag circulated, it helped draw attention to the repressive nature of the Mugabe regime and the urgent desire 
of those in Zimbabwe to break free of it. Even more important, a video posted on social media mobilized a recognizable local (and later international) protest movement against then-president Mugabe. In protests that were unprecedented in size and frequency, activists across Zimbabwe and internationally began using the Zimbabwean flag as a symbol for the resistance's "brand image." Sparked by a viral Facebook video, thousands of protesters took to the streets of Harare in the following months, demanding the departure of Robert Mugabe as president and accusing him of political misrule and economic mismanagement. The high visibility of the protests sparked international outrage when Zimbabwe's government arrested Mawarire and tried to press terrorism charges. But even though the government tried to repress Mawarire, it was too late to repress the uprising he sparked.

Facebook, Twitter, WhatsApp, and others may be useful tools, but these technologies still require a skilled strategic mind to guide their use. One excellent example of a deliberate dilemma action that creatively used technology took place recently in Spain. On April 10, 2015, No Somos Delito (We Are Not a Crime), a coalition of Spanish activist groups in Madrid, created a symbolic protest to raise awareness and to defend the obstruction of Spaniards' basic rights. Their democratic rights to freedom of expression, assembly, protest, and information were being limited by the Gag Law, also known as "La ley de seguridad ciudadana" (Citizen Safety Law). Under the Gag Law, protesting at certain locations 
would be considered a criminal act subject to a $€ 30,000$ fine. Because Spain was on the brink of a bitter and competitive election, the government really wanted to avoid news dominated by images of large crowds of protesters in front of the parliament building. Hence the Gag Law, which restricted public protest.

Undaunted, activists decided to create an alternative way to protest that allowed them to avoid being physically present in public places. Instead of going to a protest site, they created a hologram. Holograms for Freedom was a website for people around the globe, a portal for those who could not be physically present, to digitally protest in front of the Spanish Parliament. It allowed visitors to write or record their message on the website, which would then be projected in public. ${ }^{14}$ The website attracted 800,000 people globally with 300,000 signing an online petition to abolish the law. The recordings were then projected, "the first hologram protest in history." Although this was a one-off digital protest, this dilemma action opened creative avenues for defending people's fundamental human rights. While the effort did not lead to overturning the law, the resistance gained momentum and let Spanish voices be heard by news media around the globe.

This range of examples offers a glimpse of the complex ways that dilemma actions can bring about political transformation. "Dimes for Change" was successful because no one got hurt, the authorities looked foolish, lots of regular people participated (perhaps for the first time), and the media 
covered it widely. The TV-walking protest was pretty successful too, because it engaged a lot of people. Even though the earlier curfew was a form of backlash, it only served to reduce public support for the regime. \#ThisFlag was extraordinarily successful in drawing media coverage and using technology to unite online efforts with grassroots, in-person organizing, though Mawarire went to jail. Perhaps more important, all these regimes eventually fell, and these dilemma actions played a critical role in advancing those changes. On the other hand, the Holograms for Freedom did not change the law, but it was a media triumph that engaged almost a billion people around the world. In other words, "success" is measured variously, an inevitable phenomenon in complex movements that are capable of eventually bringing about change.

The purpose of these all these actions-in different parts of the world and for different kinds of struggles-is to create a dilemma for the opponent whenever its policies conflict with people's democratic rights, will, and common sense: such as the beliefs that people should be able to make salt from the ocean without paying the colonial government for it, or be able to wear a hat, or sit at lunch counters, or express any of these opinions in public. Through a long history of brilliant and entertaining dilemma actions, strategists have forced authoritarians to risk losing support no matter whether they grant or deny the demands of nonviolent opposition. 